\title{
COAL BOTTOM ASH AS A GEOMATERIAL: INFLUENCE OF PARTICLE MORPHOLOGY ON THE BEHAVIOR OF GRANULAR MATERIALS
}

\author{
Nilo Cesar Consoli ${ }^{i)}$, Karla Salvagni Heineck ${ }^{\mathrm{i})}$, Matthew Richard Coopii), \\ António Viana da Fonsecaiii) and Cristiana Ferreira ${ }^{\text {iv) }}$
}

\begin{abstract}
Previous studies of mechanical properties of solid residue byproducts such as coal bottom ash have been restricted to small and intermediate shear strains of approximately $0.1-20 \%$, due to the limitations of the standard equipment used (e.g. triaxial and direct shear tests) and to confining pressures up to around $1.5 \mathrm{MPa}$. The objective of the present research was to study the behavior of coal bottom ash sampled in southern Brazil, ranging from very small to very large shear strains, as well as to high isotropic pressures, to determine its complete behavior. Comparisons are made with results from a granular soil with a similar grading and also with those of uniform sand with similar average particle size. High pressure isotropic compression and bender element tests, as well as standard triaxial tests and ring shear tests were carried out on compacted specimens of coal bottom ash, a sandy residual soil with a similar grain size distribution, as well as on a uniform sand. In order to explain the effect of the particle morphology of the coal bottom ash on its mechanical behavior, an investigation was also undertaken based on thin section and scanning electron micrographs, which revealed intra-particle voids in the coal ash. The results indicate that the general behavior of the bottom ash compares favorably with conventional granular materials, providing a promising solution to the disposal problem, and also an economic alternative to the use of conventional soils as construction materials.
\end{abstract}

Key words: ash, compressibility, particle morphology, sand, shear modulus, strength (IGC: D3/D5/D6)

\section{INTRODUCTION}

Residues of thermo electrical power plants are generically known as ash, and can be classified as slag, bottom ash and fly ash. Slag has a high content of unburned carbon $(10 \%$ to $20 \%)$ and coarse grains or clods. Bottom ash and fly ash are produced from pulverized coal, resulting in residues with finer grain size distribution. Fly ash is dragged upwards by combustion gasses and is collected by a capitation system, or electrostatic precipitator, while bottom ash is collected at the bottom of the furnace and transported to a decantation container. Fly ash has already an effective use in the Portland cement industry as an additive to cement up to $40 \%$ in volume. Even if it is an environmentally inert residue, the possible uses of bottom ash have scarcely been studied, although the differences and similarities of the mechanical properties of bottom ash compared to soils have been investigated (e.g., Huang, 1990; Huang and Lovell, 1990; Tessari et al., 1998; Thomé et al., 1998, 2003; Kim et al., 2005).

Coal production in southern Brazil is approximately $3,000,000$ tons/year, which represents $60 \%$ of the nation- al production (Binotto et al., 1999). New thermo-electrical power plants are currently being built, generating environmental problems concerning waste disposal in this area. The primary objective of this research is therefore to contribute to the study of the mechanical behavior and morphology of thermo-electrical power plant byproducts, specifically bottom ash, in order to evaluate the possibility of its use, which would be an important contribution to environmental geotechnology.

From an environmental point of view, Sanchez (1987) and Sanchez et al. (1996) have carried out leaching tests on many bottom ashes from several sources produced by coal-burning electricity utilities in Southern Brazil, showing that they are not potentially hazardous residues, in so far as they do not exceed the limits of heavy metals of the Brazilian Standard ABNT NBR 10.004 (1987) and can be classified as inert residues. There is therefore no need for special precautions when using bottom ash in earthworks, regarding its safety for the environment. However, in order to promote their use, the mechanical properties of such materials in comparison with natural soils needs further research, including the morphological aspects of the particles, which usually shows internal

i) Associate Professor, Federal University of Rio Grande do Sul, Brazil (consoli@ufrgs.br).

ii) Reader, Imperial College, University of London, UK.

iii) Associate Professor, University of Porto, Portugal.

iv) Research Assistant, ditto.

The manuscript for this paper was received for review on March 16, 2006; approved on October 2, 2006.

Written discussions on this paper should be submitted before November 1, 2007 to the Japanese Geotechnical Society, 4-38-2, Sengoku, Bunkyo-ku, Tokyo 112-0011, Japan. Upon request the closing date may be extended one month. 
Table 1. Main mineral coal constituents for Capão do Leão coal pit (\%)—(Sánchez, 1987)

\begin{tabular}{c|c|c|c|c|c|c|c|c|c|c}
\hline $\mathrm{SiO}_{2}$ & $\mathrm{Al}_{2} \mathrm{O}_{2}$ & $\mathrm{Fe}_{2} \mathrm{O}_{3}$ & $\mathrm{CaO}$ & $\mathrm{P}_{2} \mathrm{C}_{5}$ & $\mathrm{MnO}_{2}$ & $\mathrm{TiO}_{2}$ & $\mathrm{MgO}$ & $\mathrm{Na}_{2} \mathrm{O}$ & $\mathrm{K}_{2} \mathrm{O}$ & $\begin{array}{c}\mathrm{Burning} \text { loss } \\
\left(1000^{\circ} \mathrm{C}\right)\end{array}$ \\
\hline 23.7 & 10.5 & 1.0 & 0.74 & 0.03 & $<0.01$ & 0.44 & 0.19 & 0.14 & 0.44 & 62.8 \\
\hline
\end{tabular}

porosity of the grains, resulting from the high coal burning temperature, leading to low specific gravities of the solids.

\section{BACKGROUND}

Studies of the engineering properties and the physical and chemical characteristics of bottom ash have been carried out in the laboratory and also in the field by several researchers in recent decades. Seals et al. (1972) presented laboratory data obtained from standard Proctor compaction tests on West Virginia bottom ash, as well as a series of one-dimensional compression tests showing that, at low stress levels, the compressibility of bottom ash was comparable to natural granular soils at similar relative densities. Huang (1990) and Huang and Lovell (1990) investigated the shear strength of Indiana bottom ash compacted to different densities using direct shear testing, reporting a wide range of variation of friction angles, depending on the density. Heineck (2002) studied the possibility of using coal bottom ash from thermo-electrical power plants in Southern Brazil to replace sand in embankments, provided that the bottom ash had acceptable environmental properties concerning its leachate. Kim et al. (2005) carried out an extensive experimental study involving standard compaction, hydraulic conductivity, one-dimensional and drained triaxial compression tests on specimens of fly/bottom ash mixtures. They also carried out specific gravity tests and grain size analyses, as well as a microscopic examination of the fly and bottom ash samples.

Plate load tests were carried out by Tessari et al. (1998) on layers of coal bottom ash treated with cement, which established the potential use of these materials improved by cementing. Thomé et al. (2003) used a mixture of a sandy residual soil with bottom ash in equal proportions, with the addition of lime in the improvement of an upper soil layer, on which plate load tests were then undertaken, which gave encouraging results.

However, existing studies have been restricted to small to intermediate shear strains (0.1-20\% typically) and to small to intermediate stress levels $(0-1 \mathrm{MPa})$ due to the restrictions of the standard equipment used (e.g. triaxial and direct shear tests). The present work extends this with high-pressure isotropic compression tests using bender elements to measure $G_{0}$, ring shear tests to reach very large shear strains and scanning electron microscopy. The results for compacted specimens of coal bottom ash are compared with those from the same tests carried out on a sandy residual soil with a similar grain size distribution, as well as on uniform sand with the same average particle diameter.

\section{MATERIALS}

Three different materials from southern Brazil were tested in this research; a coal bottom ash derived from a thermo-electric power plant, a sandy residual soil with similar grain size distribution and a uniform sand with a similar average particle diameter to that of the bottom ash.

\section{Coal Bottom Ash}

The coal bottom ash used in this research was collected from the Charqueadas thermo-electric Power Plant, located near Porto Alegre, in southern Brazil. This material is a by-product of the burning process of coal from the Capão do Leão coal pit, also in southern Brazil. The main mineral constituents of this coal are listed on Table 1. At the end of the burning process, bottom ash is drained from the furnace and transported to inactive coal pits that are used for disposal.

Physically, ashes have spherical or semi-spherical particles and are characterized by a complex morphology. Andrade (1985) describes ash particle formation during the burning process. The author suggests that the final product has spherical particles that can be solid (plerospheres) or hollow (cenospheres), micro-particles and crystals. The spherical particles are formed from the fusion of the carbon components of the mineral coal upon an inert surface. Drops of this melted material can combine, forming larger spheres. Hollow spheres, or cenospheres, which are formed after plerosphere formation, are produced when gases are generated inside the melted sphere resulting in its expansion. This mechanism can also form cenospheres with other spheres inside them (Gupta et al., 2001). Excessive cenosphere expansion can cause particle explosion, resulting in microparticle formation. These small particles can combine or agglomerate, forming larger irregular and sub-angular particles.

The bottom ash studied herein can be classified in geotechnical terms as a non-plastic silty-sand (SM) according to the Unified Soil Classification System (ASTM D2487, 1993). The specific gravity of the particles is 2.30 and the grain-size data are shown in Fig. 1, indicating that it is predominantly fine sand and silt. The value of the specific gravity of the particles observed for bottom ash is very low due to the internal porosity of the grains, resulting from the high coal burning temperature, as well as the presence of carbon, which has a low specific gravity. The effective diameter $\left(D_{10}\right)$ of the particles is $0.011 \mathrm{~mm}$ and the average diameter $\left(D_{50}\right)$ is $0.144 \mathrm{~mm}$. The uniformity and curvature coefficients are 2.8 and 16.4 respectively. According to Calarge et al. (1998) the 


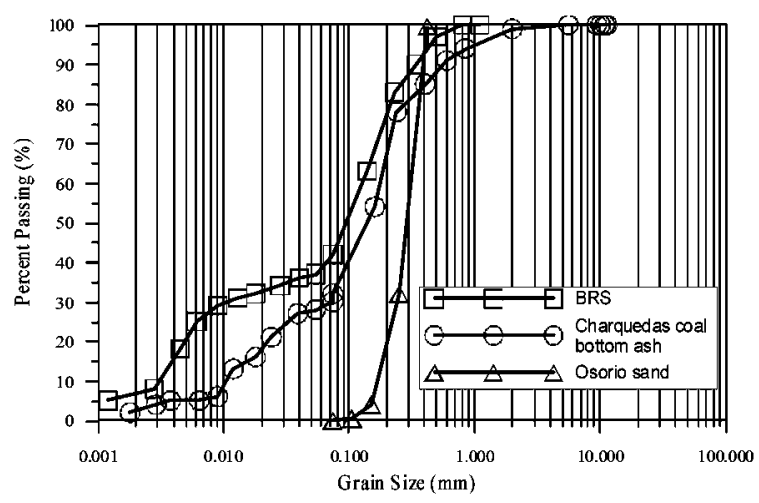

Fig. 1. Grain size distribution curves of Charqueadas coal bottom ash, Osório sand and Botucatu residual soil

Table 2. Chemical analysis of coal bottom ash from Charqueadas

\begin{tabular}{c|c|c|c|c|c|c|c}
\hline $\mathrm{SiO}_{2}$ & $\mathrm{Al}_{2} \mathrm{O}_{3}$ & $\mathrm{Fe}_{2} \mathrm{O}_{3}$ & $\mathrm{CaO}$ & $\mathrm{MgO}$ & $\mathrm{K}_{2} \mathrm{O}$ & $\mathrm{TiO}_{2}$ & Burning loss \\
\hline 64.40 & 24.50 & 4.5 & 1.31 & 0.40 & 0.14 & 1.60 & 0.14 \\
\hline
\end{tabular}

grain size distribution of the coal bottom ashes produced in Brazil (specimens sampled from the main thermoelectric Power Plants in Brazil) varies as follows: 1-10\% coarse sand $(0.6 \mathrm{~mm}<D<2.0 \mathrm{~mm}), 15-27 \%$ medium sand $(0.2 \mathrm{~mm}<D<0.6 \mathrm{~mm}), 35-44 \%$ fine sand $(0.06$ $\mathrm{mm}<D<0.2 \mathrm{~mm}), 23-34 \%$ silt $(0.002 \mathrm{~mm}<D<0.06$ $\mathrm{mm})$ and $0-2 \%$ clay $(D<0.002 \mathrm{~mm})$. The Charqueadas coal bottom ash fits in the above presented range and is representative of the coal bottom ash produced in Brazil.

A mineralogical characterization based on X-ray diffraction tests was carried out by Thomé et al. (2003) who describe the bottom ash as a material in which both crystalline and amorphous phases are observed. The crystalline phase is composed mainly of mullite and quartz, with hematite and magnetite in lower proportions. Mullite originates from reactions of kaolinite and illite-smectite during the burning process. The quartz is a mineral of detritic origin in thermo-electric calcination conditions, since it remains unmelted. Hematite and magnetite, present as secondary minerals, are formed from the oxidation of iron sulfates such as pyrite. Chemical analysis shows that the Charqueadas coal bottom ash is composed predominantly of silica, alumina and iron oxide, as well as smaller portions of calcium oxide, magnesium oxide, and other components, as shown in Table 2. The chemical analysis of the specimens sampled from the main thermo-electric Power Plants in Brazil were also investigated by Calarge et al. (1998), revealing the following ranges of percentages for the main oxides found: from 62.5 to $66.7 \% \mathrm{SiO}_{2}, 19.2$ to $24.6 \% \mathrm{Al}_{2} \mathrm{O}_{3}$, 7.1 to $9.0 \% \mathrm{Fe}_{2} \mathrm{O}_{3}, 0.6$ to $1.7 \% \mathrm{CaO}, 0.3$ to $0.4 \% \mathrm{MgO}$, 0.1 to $0.2 \% \mathrm{~K}_{2} \mathrm{O}$ and 1.2 to $2.4 \% \mathrm{TiO}_{2}$. The Charqueadas coal bottom ash falls into the above cited ranges. The same study also shows that the Brazilian coal bottom ashes have a quite similar chemical composition to Brazilian coal fly ashes from the same sources.

Microscope analyses were carried out based on resin-

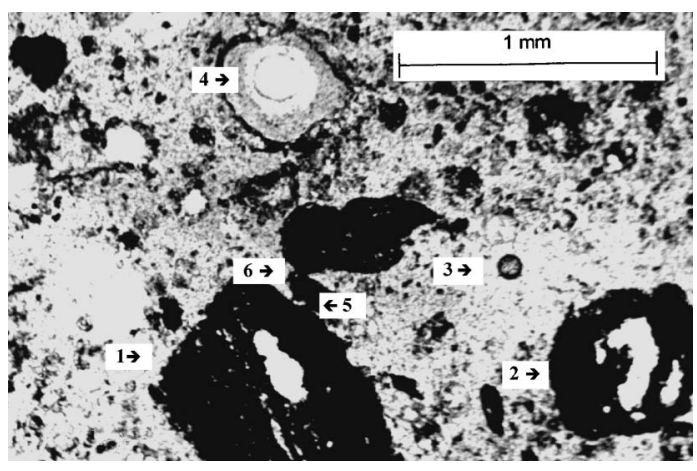

Fig. 2. Thin section micrograph of Charqueadas coal bottom ash

Table 3. Grading intervals of ash samples analyzed in the optical microscope

\begin{tabular}{l|l|l}
\hline \multirow{2}{*}{$\begin{array}{c}\text { Charqueadas } \\
\text { coal bottom }\end{array}$} & Fine fraction $(>\# 100$ and $<\# 200)$ & 0.075 to $0.15 \mathrm{~mm}$ \\
\cline { 2 - 3 } \begin{tabular}{l} 
ash \\
\cline { 2 - 3 }
\end{tabular} & Medium fraction $(<\# 40$ and $>\# 60)$ & 0.25 to $0.425 \mathrm{~mm}$ \\
\cline { 2 - 3 } & Coarse fraction $(<\# 10$ and $>\# 20)$ & 0.85 to $2.0 \mathrm{~mm}$ \\
\hline
\end{tabular}

impregnated thin sections, using a transmitted light optical microscope. Some samples were also impregnated with color in order to define better the voids. The thin sections were obtained by cutting the impregnated specimens, sticking them to a glass slide and polishing them until they reached the desired thickness for observation. The particle texture and morphology, determined in conventional optical microscopy, show turbid (opaque) angular and sub-angular particles that remain from the unburned coal fraction (Fig. 2, detail 1). Unburned and partially burned material can be seen in Fig. 2, as well as the intra-particle porosity caused by particle expansion, suggesting transition between plerospheres (Fig. 2, detail 3) and cenospheres (Fig. 2, details 1,2 and 4). The spherical particles are opaque (Fig. 2, detail 3) and/or translucent (Fig. 2, detail 4). The finer fraction is derived from partially burned particles breaking due to gas expansions inside them.

Samples were made of the bottom ash impregnated with colored resin for different gradings: fine, medium and coarse, which were separated by sieving, in order to understand better the particle morphology, as can be seen in Table 3. Optical microscope observation shows that bottom ash has a large variation in grain size and shape (Fig. 3), with predominantly angular and sub-angular particles of opaque and translucent material. Spherical bodies (cenospheres and plerospheres) that are both opaque (Fig. 3(b) detail 3) and translucent (Fig. 3(a) detail 2, Fig. 3(c) detail 6) are equally frequent. The grains tend mainly to have point contacts (Fig. 2, detail 5), which were defined by Pettijohn et al. (1987) as single small punctual contacts between grains. There are only rarely longitudinal contacts (Fig. 2, detail 6), defined as one long contact (or multiple contacts) between two grains. The opaque and translucent particles are porous and irregular in shape (Fig. 3(a) detail 1, Fig. 3(b) detail 


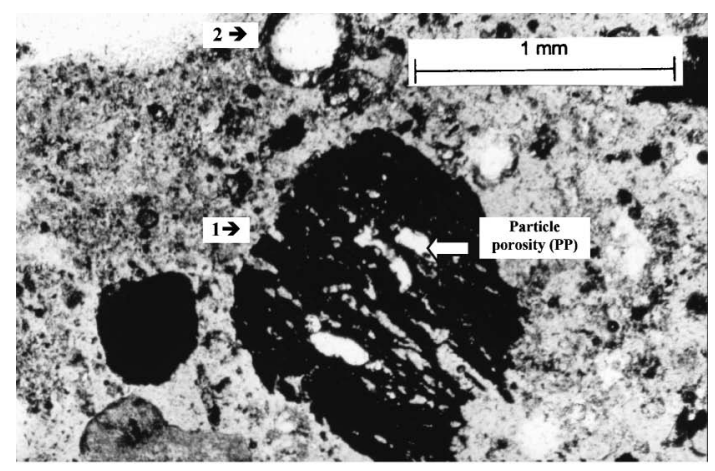

(a) Charqueadas coal bottom ash - coarse fraction ( 0.85 to $2 \mathrm{~mm})$

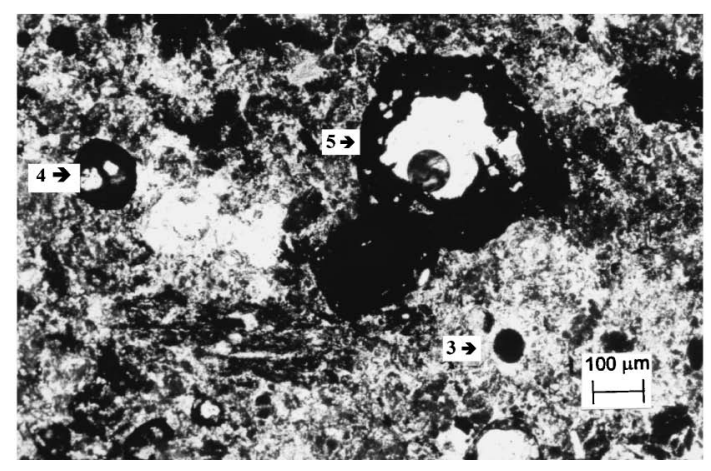

(b) Charqueadas coal bottom ash - medium fraction $(0.25$ to $0.42 \mathrm{~mm})$

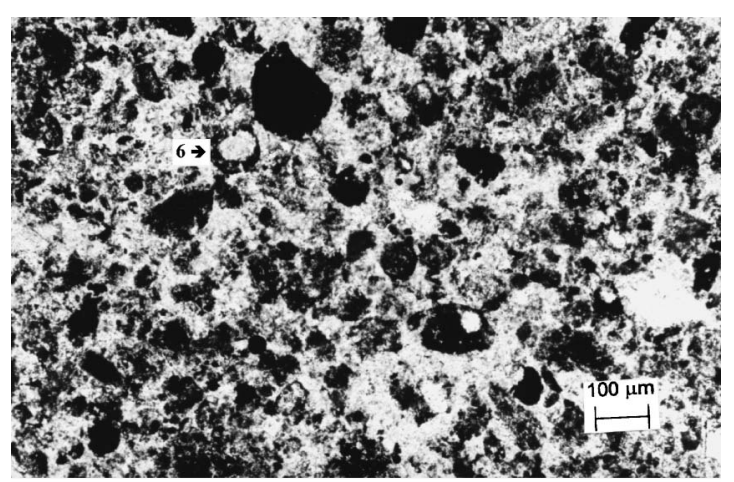

(c) Charqueadas coal bottom ash - fine fraction $(0.075$ to $0.15 \mathrm{~mm})$

Fig. 3. Thin section micrographs of Charqueadas coal bottom ash separated by grading: (a) coarse fraction, (b) medium fraction and (c) fine fraction

5), which could be responsible for the high hydraulic conductivity of this material. The orientation of the intra-particle pores (defined as PP-Fig. 3(a)) is related to the primary sedimentary structure of the material. The pores indicated on the figure correspond to carbonaceous material that has expanded and vaporized during the coal burning process. Another interesting feature is the occurrence of permeable cenospheres (hollow spheresFig. 3(c) detail 6), suggesting particle fragility due to the intra-particle voids.

Microscopic analysis of bottom ash particles by means of scanning electron microscope (SEM) was also carried out, aimed at confirming the existence of the pores in the ash particles that were observed in the optical microscope micrographs (e.g. Fig. 3(a)). The sample preparation was based on the procedures described by Tovey (1986). As

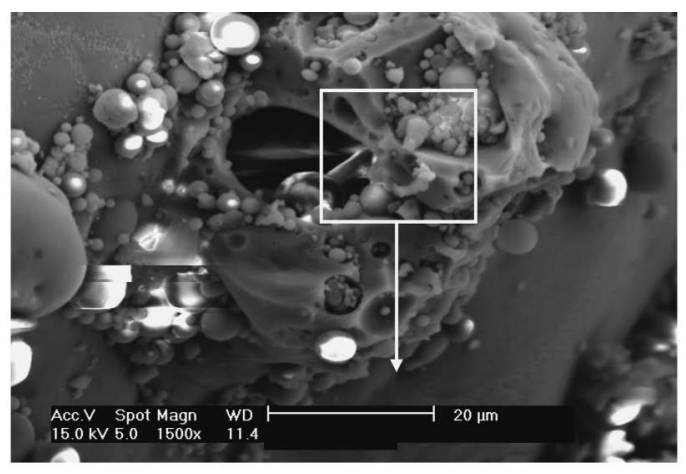

(a)

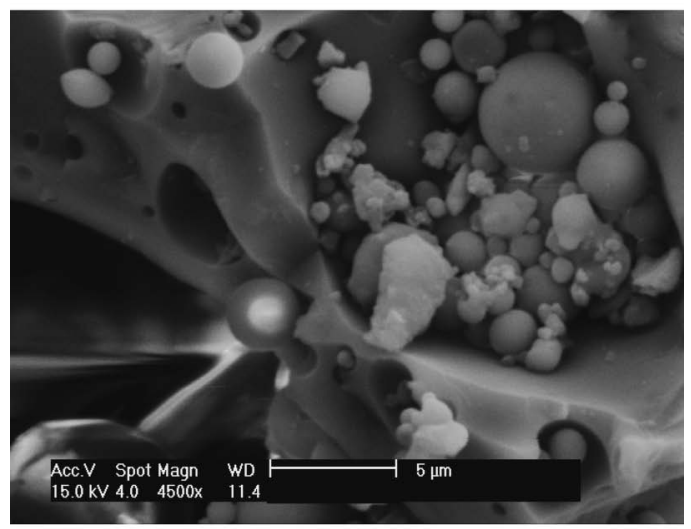

(b)

Fig. 4. Scanning Electron Photomicrographs of internal porosity of the grains of Charqueadas coal bottom ash $\{(b)$ is an enlargement of the area highlighted in (a) $\}$

electron microscopes operate under high vacuum, it was necessary to remove the pore fluids through drying and before observation the sample was vacuum coated with a thin layer $(20 \mathrm{~nm})$ of gold. The micrographs were generated with secondary electron images, and it was therefore important to coat the particles with an element of high atomic number (in the present case-gold) as this improves the signal-to-noise ratio. The SEM images in Fig. 4 show the intra-particle voids and spherical bodies previously observed in the optical microscope micrographs.

Finally, results obtained from leaching tests revealed that the bottom ash from Charqueadas does not exceed the limits of heavy metals of the Brazilian Standard ABNT NBR 10004 (1987), being classified as an inert residue (Thomé et al., 2003).

\section{Osório Sand}

The sand used in the present study was sampled from the region of Osório, in southern Brazil. The soil is classified as a non-plastic uniform fine sand (SP) according to the Unified Soil Classification System (ASTM D2487, 1993). The specific gravity of the particles is 2.63 and the grain size distribution is completely within the fine sand range, as can be seen in Fig. 1. The effective diameter $\left(D_{10}\right)$ of the particles is $0.16 \mathrm{~mm}$, the average diameter $\left(D_{50}\right)$ is $0.29 \mathrm{~mm}$, and the uniformity and 


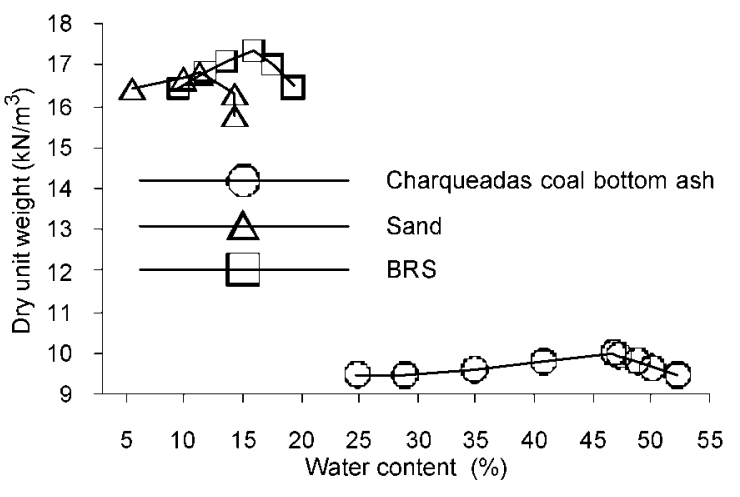

(a)

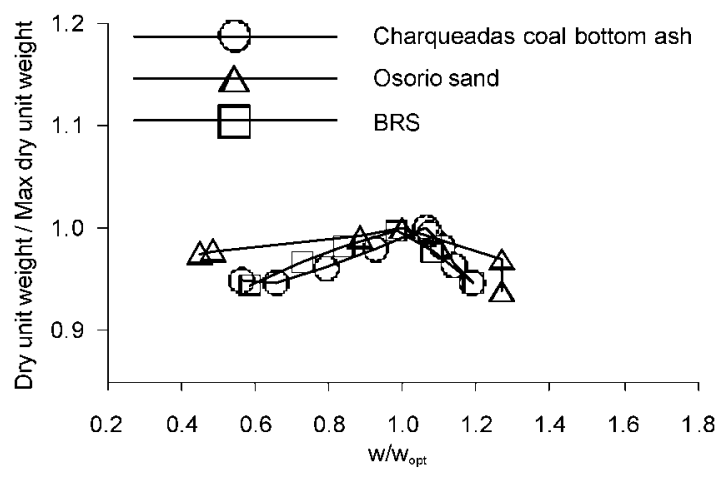

(b)

Fig. 5. Compaction curves for all materials studied (a) usual and (b) normalized curves

curvature coefficients are 1.9 and 1.2 respectively. Mineralogical analysis showed that the sand particles are predominantly quartz. The minimum and maximum void ratios are 0.57 and 0.85 respectively. The particles are rounded to sub-rounded in shape, with a few sub-angular grains.

\section{Botucatu Residual Soil (BRS)}

The Botucatu Residual Soil is derived from weathered sandstone and was also obtained from the region of Porto Alegre. The soil is classified as a non-plastic silty sand (SM) according to the Unified Soil Classification System (ASTM D2487, 1993). The specific gravity of the particles is 2.65 and the grain-size data indicate that it is predominantly fine sand and silt, as can be seen in Fig. 1 . The effective diameter $\left(D_{10}\right)$ of the particles is $0.0031 \mathrm{~mm}$ and the average diameter $\left(D_{50}\right)$ is $0.09 \mathrm{~mm}$. The liquid limit is $22 \%$ and the plastic limit is $19 \%$. X-ray diffraction showed that the fine portion is predominantly kaolinite.

\section{EXPERIMENTAL PROGRAM}

Standard Proctor compaction tests were carried out on samples of Charqueadas coal bottom ash, Osório sand and BRS, as shown in Fig. 5, in the usual $\left(\gamma_{\mathrm{d}}-w\right)$ and normalized $\left(\gamma_{\mathrm{d}} / \gamma_{\mathrm{dmax}}-w / w_{\text {opt }}\right)$ plots. In Fig. 5(a) it is possible to observe that the maximum dry unit weight of the coal bottom ash is much smaller that the value for
Table 4. Molding parameters adopted in the experimental program, related to Standard Proctor Energy

\begin{tabular}{l|c|c|c}
\hline \multirow{2}{*}{ Soil matrix } & \multicolumn{3}{|c}{ Molding parameters } \\
\cline { 2 - 4 } & $\begin{array}{c}\text { Optimum } \\
\text { water } \\
\text { content } \\
(\%)\end{array}$ & $\begin{array}{c}\text { Maximum dry } \\
\text { unit weight } \\
\left(\mathrm{kN} / \mathrm{m}^{3}\right)\end{array}$ & $\begin{array}{c}\text { Relative degree } \\
\text { of compaction }\end{array}$ \\
\hline $\begin{array}{c}\text { Charqueadas } \\
\text { coal bottom ash }\end{array}$ & 44.0 & 10.0 & $100 \%$ \\
\hline BRS & 16.2 & 17.4 & $100 \%$ \\
\hline Osório sand & 10.0 & $15.9^{*}$ & $70 \%\left(D_{\mathrm{r}}\right)$ \\
\hline
\end{tabular}

* Dry unit weight used was associated to the relative density of $70 \%$, (value is smaller than the value correlated to the maximum dry unit weight of Standard Proctor Procedure).

both Osório sand and BRS, certainly due to its intraparticle pores. The optimum moisture content of the coal bottom ash is also much larger than the other two soils studied. However, in Fig. 5(b) it is possible to observe that once normalized, the curves for the three materials have a quite similar form.

\section{Sample Preparation}

The compacted soil specimens used in the conventional triaxial tests and the high-pressure isotropic compression tests with bender element measurements of shear wave velocity were prepared by hand-mixing dry soil and water. The under compaction process (Ladd, 1978) was used to produce homogeneous specimens that could be used for a parametric study in the laboratory-testing program. The specimens were statically compacted in three layers into a $50 \mathrm{~mm}$ diameter by $100 \mathrm{~mm}$ high split mould, at a moisture content and dry unit weight taken from Table 4. For the BRS and Charqueadas coal bottom ash, the values presented were related to the optimum compaction parameters based on standard Proctor compaction tests. In the case of the Osório sand, specimens were directly made in a mould on the triaxial pedestal at a relative density of $70 \%$. For the ring shear tests, the specimens were also prepared by hand-mixing dry soil, although each sample was compacted directly into the confining rings (with an inner and outer diameter of $101.6 \mathrm{~mm}$ and $152.4 \mathrm{~mm}$ respectively and an initial height of approximately $25.4 \mathrm{~mm}$ ) by applying a static load via the annular loading platen. The final height of the sample was controlled to ensure the correct initial density.

\section{High-pressure Isotropic Compression Tests}

The high-pressure isotropic compression tests were conducted using two computer controlled stress path apparatus with cell pressure capacities of $8 \mathrm{MPa}$ and $70 \mathrm{MPa}$. In both apparatus the cell chamber is oil-filled because water-submersible internal instrumentation would not withstand these pressures, and so the internal axial strains are measured locally on the sample with standard non-submersible Linear Variable Differential Transformers (LVDTs) drilled with pressure relieving 


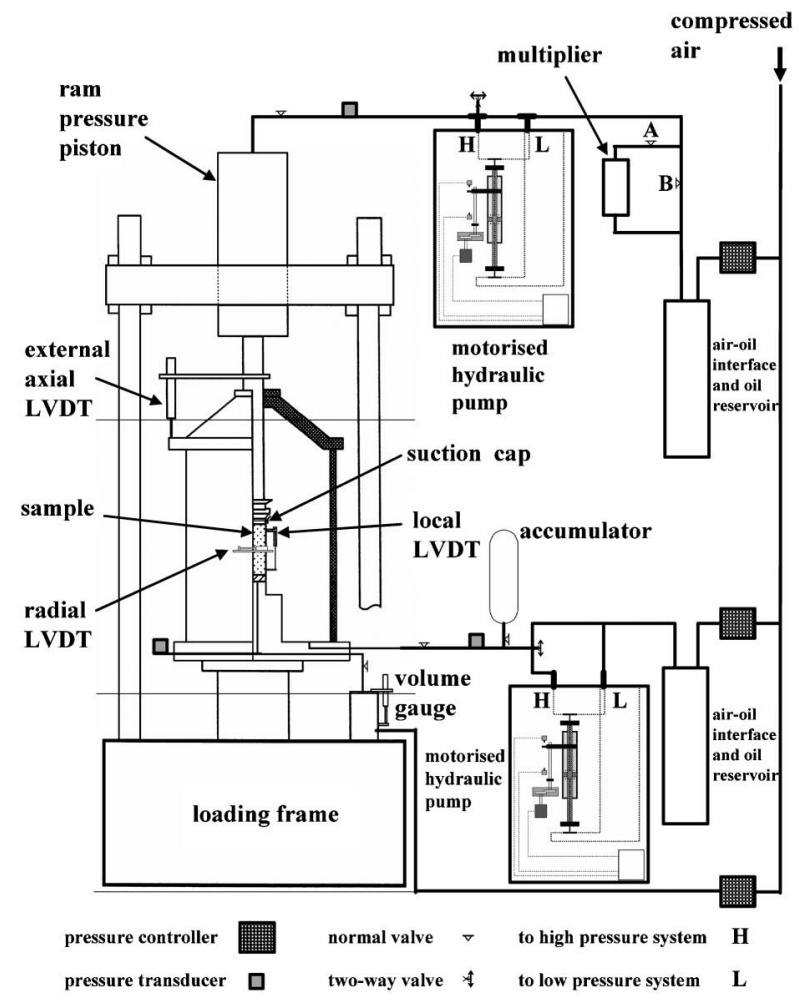

Fig. 6. The $8 \mathrm{MPa}$ high pressure apparatus (after Qadimi, 2005)

holes to allow the oil into and out of the transducer body, as described by Cuccovillo and Coop (1997). Both apparatus are also fitted with an LVDT to measure axial strains outside the cell, although here, for isotropic compression, only the measurements of volume change are used. These were made with an Imperial College type volume gauge, working at standard pressures $(0-700 \mathrm{kPa})$ and attached to the back-pressure line.

Figure 6 shows a schematic diagram of the $8 \mathrm{MPa}$ apparatus. For conventional pressures, up to $700 \mathrm{kPa}$ the cell pressure and axial stress are adjusted by means of computer controlled air pressure regulators acting through air-oil interfaces, the axial stress then being applied to the sample via a hydraulic cylinder mounted above the triaxial cell. The back pressure is controlled by means of a similar pressure regulator with its air output attached to the base of the volume gauge, which also acts as the air-water interface. Higher pressures may be achieved through a second control system which uses motorized hydraulic pumps, again controlled by computer, to deliver up to $8 \mathrm{MPa}$ into the cell pressure or stress systems. The axial pressure system has in addition an intermediate pressure control system consisting of a pressure multiplier placed in-line after the air-oil interface, which multiplies the oil pressure delivered by 2.5 times. In each case the cell pressure and axial stress are controlled by means of a feedback loop from the cell pressure and deviatoric force transducers, the computer adjusting the air pressure input or the motorized hydraulic pump as appropriate.

The $70 \mathrm{MPa}$ system is described in detail by Cuccovillo and Coop (1999a), but is essentially similar to the $8 \mathrm{MPa}$ system. In place of the two motorized hydraulic pumps, two pressure multiplier pumps deliver high-pressure oil to the cell chamber and axial loading cylinder at a ratio of 100 times the input air pressure. The cell pressure and axial stress are then again controlled by means of a feedback loop from the cell pressure and deviatoric force transducers, the computer adjusting the air pressure input to the multipliers by means of the computer controlled pressure regulators.

\section{Bender Element Tests}

Introduced by Shirley and Hampton (1977), bender elements are now a standard technique for deriving the elastic shear modulus $G_{0}$ of a soil. The velocity of a shear wave propagating across the specimen $V_{\mathrm{s}}$ is measured from which $G_{0}$ may be determined:

$$
G_{0}=\rho V_{\mathrm{s}}^{2}=\rho\left(\frac{L^{2}}{t^{2}}\right)
$$

where $\rho$ is the total mass density of the soil, $L$ is the tip to tip length between the elements and $t$ is the travel time of the shear wave through the sample. The bender element tests were carried out in the two high-pressure stress path apparatus, compressing the samples isotropically at a constant rate of stress of around $150 \mathrm{kPa} /$ hour. The test procedures and methods of interpretation followed those of Jovicic et al. (1996), using a single shot sine wave with measurement of the wave velocity at the first arrival, taking care to use sufficiently high frequencies to avoid near field effects. For each reading a range of frequencies was tried, ensuring that the measured arrival time was not frequency dependent. A $10 \mathrm{~V}$ amplitude was used as the input to the transmitting element, for which Rio (2006) has shown that for soils of this range of stiffness, the maximum strain imposed should be less that $0.001 \%$ and so within the elastic range of behavior of the soils investigated.

\section{Conventional Triaxial Tests}

The triaxial tests were carried out with the samples fully saturated using effective confining pressures ranging from $20 \mathrm{kN} / \mathrm{m}^{2}$ to $200 \mathrm{kN} / \mathrm{m}^{2}$, consistent with the stresses applied in most engineering applications. Saturation was monitored in each test, ensuring $B$ values of at least 0.97 for all specimens. The axial and radial strains were monitored inside the triaxial cell by Hall effect transducers (Clayton and Khatrush, 1986; Clayton et al., 1989). The volumetric strain was measured by an Imperial College volume gauge (Maswoswe, 1985) connected to the drainage outlet. Full drainage during shearing was ensured by using a sufficiently low axial strain rate $(0.017 \% / \mathrm{min})$, and verified by measuring the excess pore pressure at the opposite end of the specimen to the drainage. Membrane and area corrections were applied following the recommendations made by La Rochelle et al. (1988). 


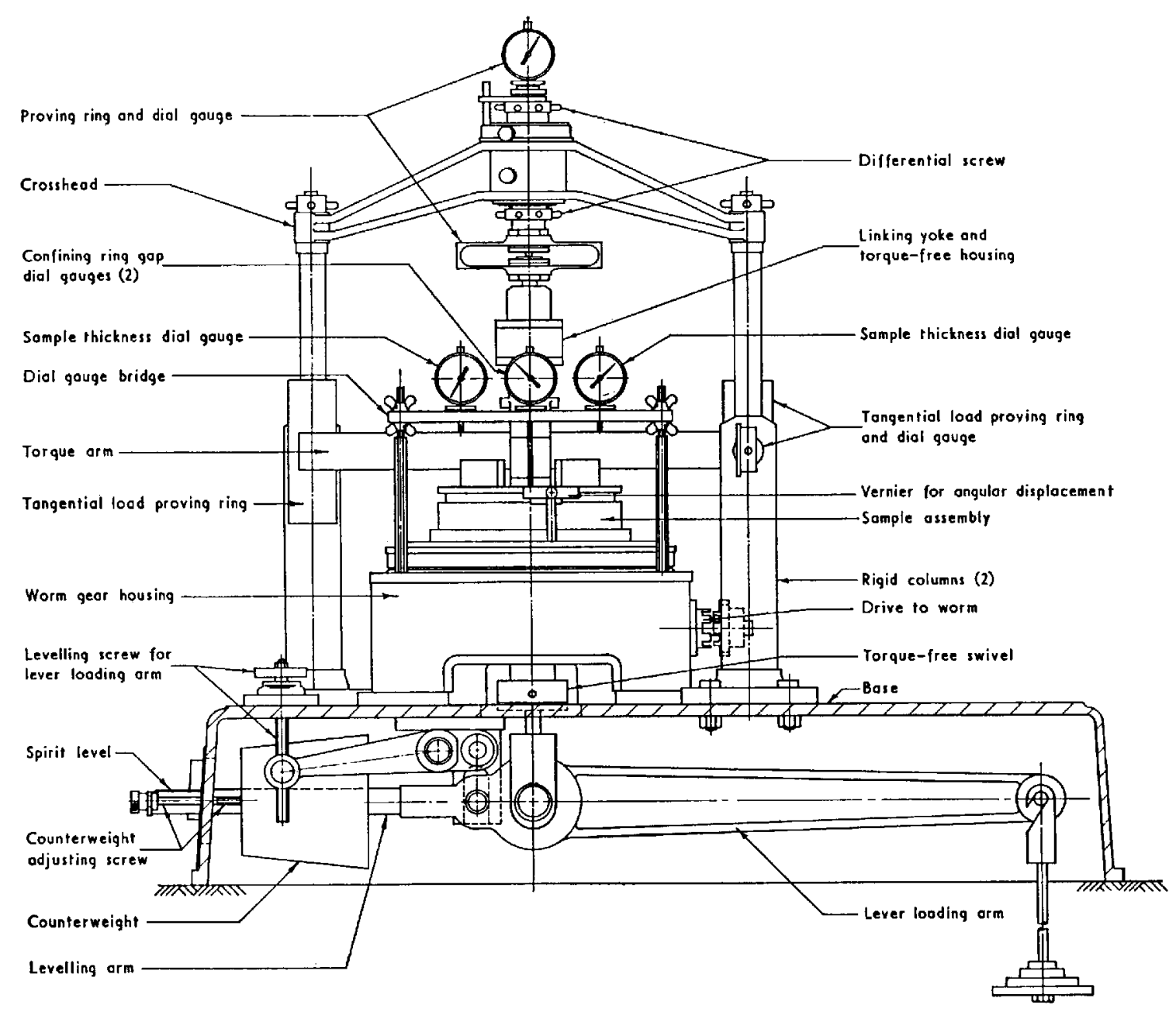

Fig. 7. The ring shear appararatus after (Bishop et al., 1971)

\section{Ring Shear Tests}

The apparatus used and general procedures for the sample preparation and testing are described by Bishop et al. (1971). In this apparatus, the lower half of the sample is carried on a rotating table driven by a worm gear, while the upper half of the sample reacts via a torque arm against a pair of fixed load cells that measure the tangential force (see Fig. 7). The shearing therefore takes place at the mid-height of the sample. The gap between the upper and lower confining rings and the side friction can be measured by means of a guided linking yoke and a proving ring connected by a screw to the rigid crosshead. After molding the sample between the pairs of lower and upper confining rings, it was then loaded by a dead-load lever system in order to apply the desired normal stress and the sample was immersed by flooding the water bath. Soon after the deformations caused by the consolidation had ceased, the locking screws were removed, the gap between the upper and lower pairs of confining rings was opened to between $0.3 \mathrm{~mm}$ and $0.35 \mathrm{~mm}$, and the sample was sheared at a constant rate of displacement of 0.17 $\mathrm{mm} / \mathrm{min}$ until horizontal displacements up to $250 \mathrm{~mm}$ were reached.

\section{RESULTS AND ANALYSIS}

The behaviors of the three different granular materials, examined through the use of high pressure isotropic compression, bender element, drained triaxial, and ring shear tests were investigated in order to evaluate whether coal bottom ash has similar mechanical properties to those of granular soils with similar gradations (e.g. BRS) or standard homogeneous sands with a similar average grain size (e.g. Osório sand), or if particle morphology, particularly the intra-particle voids of the coal ash, influences its behavior.

The isotropic compression data for the Charqueadas bottom ash, Osório sand and Botucatu residual soil (BRS) specimens are given in Fig. 8. The key feature to observe is that the Normal Compression Line (NCL) has been reached for all specimens when plotted in specific volume $(v): \ln p^{\prime}$ space. As suggested by Coop and Lee (1993) for quartzitic sands, pressures higher than $10 \mathrm{MPa}$ are often necessary to reach the NCL and in the case of Osório sand, about $15 \mathrm{MPa}$ was necessary. In contrast, the Charqueadas bottom ash reaches its NCL at isotropic pressures of about $2 \mathrm{MPa}$. The much lower yield stress compared to the Osório sand is likely to result from the 
higher initial specific volumes and more easily crushable nature of the bottom ash, resulting both from the internal porosity of the particles and their more angular shape. In this respect the behavior of the bottom ash is similar to that of biogenic carbonate sands (e.g. Coop and Lee, 1993) that also have weak particles and high initial specific volumes due to their angularity and their intraparticle voids. However, it was the Botucatu residual soil that required the lowest stress to reach its NCL (about $500 \mathrm{kPa}$ ). This is a well-graded soil, and so this shows that besides the grain morphology, the grain size distribution is also important in the definition of the pressure required to reach the NCL. However here the grain size distributions of the BRS and bottom ash are actually

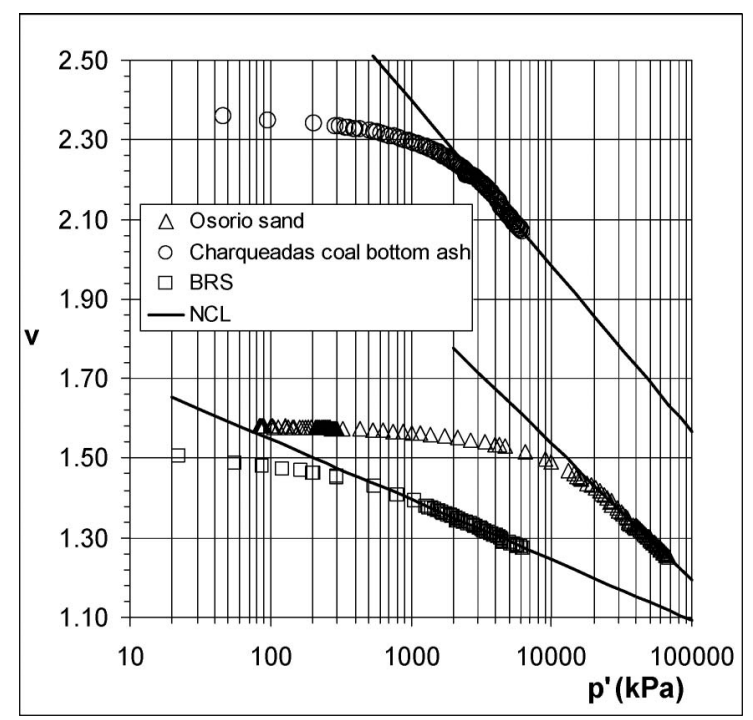

Fig. 8. High-pressure isotropic compression tests on Charqueadas coal bottom ash, Osório quartzitic sand and BRS similar-in fact BRS has a higher amount of fines-and the difference in behavior must therefore result from the intra-particle voids of the ash and differences in particle shape.

Coop and Lee (1993) have shown that the diversity of geological origins and consequent variety of particle sizes, shapes and strengths, gave a wide range of NCL locations for sands. The location of the NCL may be expressed by:

$$
v=N-\lambda \ln p^{\prime}
$$

and the values of the compressibility parameters $(N, \lambda)$ of the three materials studied in the present work, together with data from other granular soils, are shown in Table 5. The steep line of the Charqueadas bottom ash is probably related to its high initial specific volume and crushability, which are probably both related to the particle angularity and intra-particle porosity rather than its grading. The Botucatu residual soil has a flat NCL with a lower location in the $v: \ln p^{\prime}$ plane, possibly due to the grain size distribution of the material and the presence of fines. Coop and Atkinson (1993) showed that for sands a flattening of the grading curve resulted in a flattening of the NCL in the $v: \ln p^{\prime}$ plane and Coop and Lee (1993) found that the well-graded nature of a residual soil tended to give it higher initial densities, and again a flatter NCL. The other residual soils presented in Table 5 show similar features of low $N$ and $\lambda$ values amongst the materials studied here. The poorly-graded Osório sand has intermediate values of $N$ and $\lambda$, quite similar to the other quartzitic sands in Table 5.

The elastic shear modulus $\left(G_{0}\right)$ at very small strains was obtained with bender elements. The shear modulus, $G$, is typically believed to be proportional to the effective stress level raised to an exponent $n$, which varies with the strain

Table 5. Compressibility parameters of materials studied in present work and other granular soils

\begin{tabular}{l|l|l|l}
\hline \multicolumn{1}{c|}{ Soil } & $N$ & \multicolumn{1}{c}{$\lambda$} & \multicolumn{1}{c}{ References } \\
\hline Charqueadas coal bottom ash & 3.65 & 0.181 & Present work \\
\hline Botucatu residual soil (BRS) & 1.85 & 0.066 & Present work \\
\hline Osório sand (quartz) & 2.91 & 0.149 & Present work \\
\hline Chattahochee River sand (quartz) & 3.25 & 0.175 & Vesic and Clough (1968) \\
\hline Ham River sand (quartz) & 3.17 & 0.160 & Coop and Lee (1993) \\
\hline Toyoura sand (quartz) & 3.20 & 0.159 & Miura and Yamonouchi (1975) \\
\hline Antioch sand (quartz) & 3.47 & 0.200 & Lee and Seed (1967) \\
\hline Reconstituted Lower Greensand (quartz) & 3.20 & 0.158 & Cuccovillo and Coop (1999b) \\
\hline Cambria sand (quartz and lithic grains) & 2.80 & 0.138 & Lade and Bopp (2005) \\
\hline Dog's Bay sand (carbonate) & 4.80 & 0.335 & Coop and Lee (1993) \\
\hline Rankin sand (carbonate) & 3.48 & 0.200 & Coop and Airey (2003) \\
\hline Decomposed granite (Porto) & 1.89 & 0.051 & Viana da Fonseca (1996, 2003) \\
\hline Decomposed granite (Korea) & 2.15 & 0.087 & Coop and Lee (1993) \\
\hline Decomposed granite (Italy) & 1.82 & 0.064 & Santucci de Magistris et al. (1998) \\
\hline
\end{tabular}


level (e.g. Viggiani and Atkinson 1995). The value of the exponent $n$ is usually in the range 0.5 to 1 . For clays the general relationship between $G$ and the current state is of the form:

$$
\frac{G}{p_{\mathrm{r}}}=A\left(\frac{p^{\prime}}{p_{\mathrm{r}}}\right)^{n} R_{0}^{m}
$$

This relationship is often linear in the normalized plane $\log G / p_{\mathrm{r}}: \log p^{\prime} / p_{\mathrm{r}}$ where $p_{\mathrm{r}}$ is a reference pressure; $A, m$ and $n$ depend on the nature of the soil and $R_{0}$ is the overconsolidation ratio (Viggiani and Atkinson, 1995). For sands and residual soils Jovicic and Coop (1997) showed that that a similar expression could be used. However, since a sand might exist at a state below its NCL simply because it had not been loaded to sufficient stress to reach the NCL rather than through overconsolidation, the equation is modified as:

$$
\frac{G}{p_{\mathrm{r}}}=A\left(\frac{p^{\prime}}{p_{\mathrm{r}}}\right)^{n}\left(\frac{p_{\mathrm{e}}^{\prime}}{p^{\prime}}\right)^{c}
$$

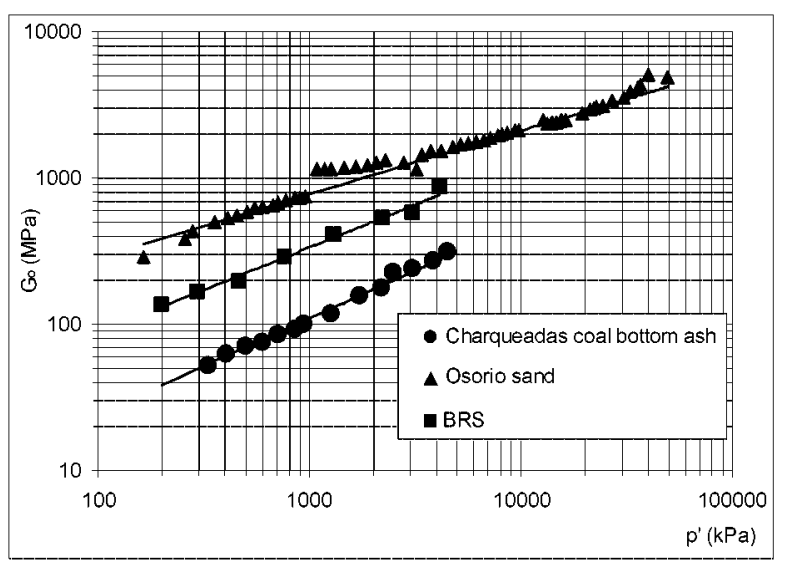

Fig. 9. Elastic shear moduli $\left(G_{0}\right)$ versus isotropic compression pressure of Charqueadas coal bottom ash, Osório quartzitic sand and Botucatu residual soil where $p_{\mathrm{e}}^{\prime}$ is an equivalent pressure at the current specific volume on the NCL and $c$ is an exponent that depends on the compression history of the sand.

Since the bender elements measure the elastic stiffness at very small strains, $G_{0}$, for states on the NCL Eq. (4) may be re-written as:

$$
\frac{G_{0}}{p_{\mathrm{r}}}=A_{0}\left(\frac{p^{\prime}}{p_{\mathrm{r}}}\right)^{n_{0}}
$$

The values of $G_{0}$ from the high pressure tests where the state of the sand is on or close to the NCL are presented in Fig. 9 (values of $G_{0} / p_{\text {r }}$ are plotted against $p^{\prime} / p_{\mathrm{r}}$, both with a logarithmic scale, where $p_{\mathrm{r}}$ has been taken as $1 \mathrm{kPa}$ ) for the Charqueadas bottom ash, Osório sand and Botucatu residual soil (BRS). It can be observed that the Charqueadas bottom ash has the lowest values of $G_{0}$, followed by BRS and finally the Osório sand, which has the largest values of elastic shear modulus for a given $p^{\prime}$.

The data points in Fig. 9 fall close to a straight line given by Eq. (5). The coefficients $A_{0}$ and $n_{0}$ obtained by fitting a straight line through the available data are equal to 1206 and 0.653 for the Charqueadas bottom ash and 5186 and 0.596 for the BRS (see Table 6), which are within the range of variation observed for conventional granular materials. In contrast, the values of coefficients $A_{0}$ and $n_{0}$ are 39470 and 0.432 for the Osório sand. Although the gradient $n_{0}$ is quite low compared to most sands, the high value of $A_{0}$ gives the Osório sand higher $G_{0}$ values than the other soils over the stress range investigated.

The curves of deviatoric stress $\left[q=\left(\sigma_{1}^{\prime}-\sigma_{3}^{\prime}\right)\right]$ and volumetric strain plotted against shear strain $\left(\varepsilon_{\mathrm{s}}=\varepsilon_{\mathrm{a}}-\varepsilon_{\mathrm{v}} / 3\right.$, where $\varepsilon_{\mathrm{a}}$ is the axial strain and $\varepsilon_{\mathrm{v}}$ the volumetric strain) obtained from the CID tests are shown in Fig. 10. The initial voids ratios at the start of shearing that are indicated on the figure are much higher for the Bottom ash than the other two soils, despite being compacted to the maximum density from the standard Proctor test. This

Table 6. Comparison of parameters $A_{0}$ and $n_{0}$ of materials studied in present work and other granular soils

\begin{tabular}{l|c|c|l}
\hline \multicolumn{1}{c|}{ Soil } & $A_{0}$ & \multicolumn{1}{c}{$n_{0}$} & \multicolumn{1}{c}{ Reference } \\
\hline Charqueadas coal bottom ash & 1206 & 0.653 & Present work \\
\hline Botucatu residual soil (BRS) & 5186 & 0.596 & Present work \\
\hline Osório sand (quartz) & 39470 & 0.432 & Present work \\
\hline Ham river sand (quartz) & 3899 & 0.593 & Jovicic and Coop (1997) \\
\hline Reconstituted lower greensand (quartz) & 4020 & 0.580 & Cuccovillo and Coop (1999b) \\
\hline Dog's bay sand (carbonate) & 3096 & 0.686 & Jovicic and Coop (1997) \\
\hline Rankin sand (carbonate) & 1632 & 0.685 & Coop and Jovicic (1999) \\
\hline Decomposed granite (Porto) & 2737 & 0.674 & $\begin{array}{l}\text { Ferreira (2002); Viana da } \\
\text { Fonseca et al. (2004) }\end{array}$ \\
\hline Decomposed granite (Korea) & 763 & 0.884 & Jovicic and Coop (1997) \\
\hline Decomposed granite (Hong Kong) & 14254 & 0.524 & Coop and Jovicic (1999) \\
\hline Decomposed granite (Italy) & 2445 & 0.738 & $\begin{array}{l}\text { Santucci de Magistris et al. } \\
\text { (1998) }\end{array}$ \\
\hline
\end{tabular}




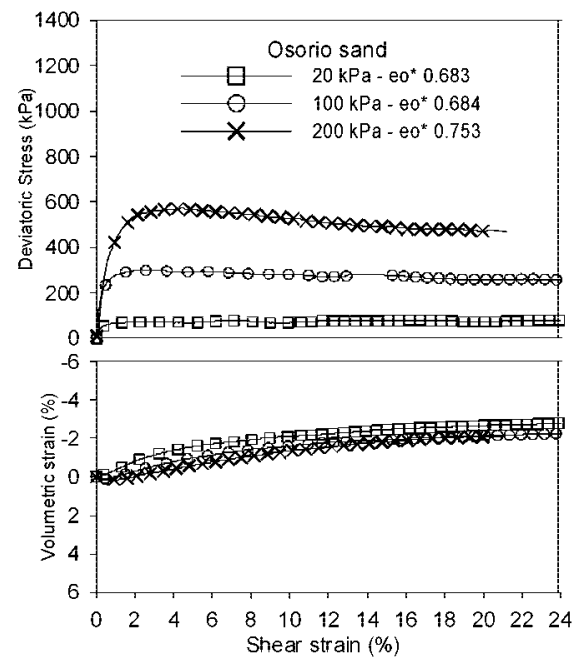

(a)

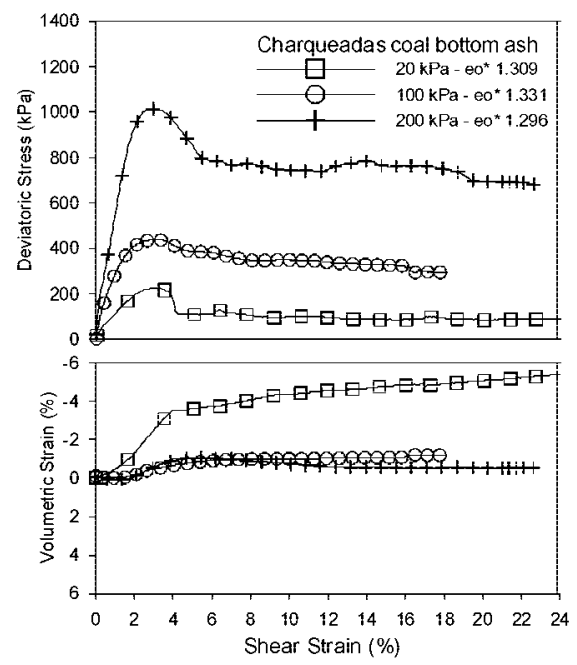

(b)

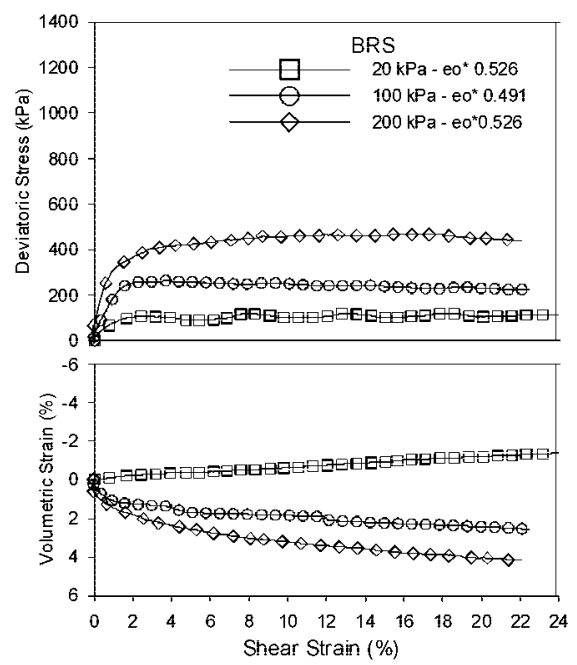

(c)

Fig. 10. Stress-strain-volumetric response from CID standard triaxial tests for (a) Osório sand, (b) Charqueadas coal bottom ash and (c) Botucatu residual soil $\left(e_{0}^{*}=e_{0}\right.$ before shearing)

again reflects the particle morphology of angularity with intra-particle voids. However, even at such high voids ratios, the Bottom ash is still dilative, with peaks in the
Table 7. Peak and ultimate shear strength parameters of materials studied in present work

\begin{tabular}{l|c|c|c}
\hline \multirow{2}{*}{\multicolumn{1}{c|}{ Material }} & \multicolumn{2}{|c|}{ Triaxial tests } & Ring shear tests \\
\cline { 2 - 4 } & $\begin{array}{c}c_{\text {peak }}^{\prime} \\
(\mathrm{kPa})\end{array}$ & $\begin{array}{c}\phi_{\text {peak }}^{\prime} \\
(\text { degrees })\end{array}$ & $\phi_{\text {ultimate }}^{\prime}$ (degrees) \\
\hline Charqueadas coal bottom ash & 12.7 & 44.7 & 35.0 \\
Osório sand & 0 & 35.8 & 26.6 \\
BRS & 11.2 & 30.5 & 20.8 \\
\hline
\end{tabular}

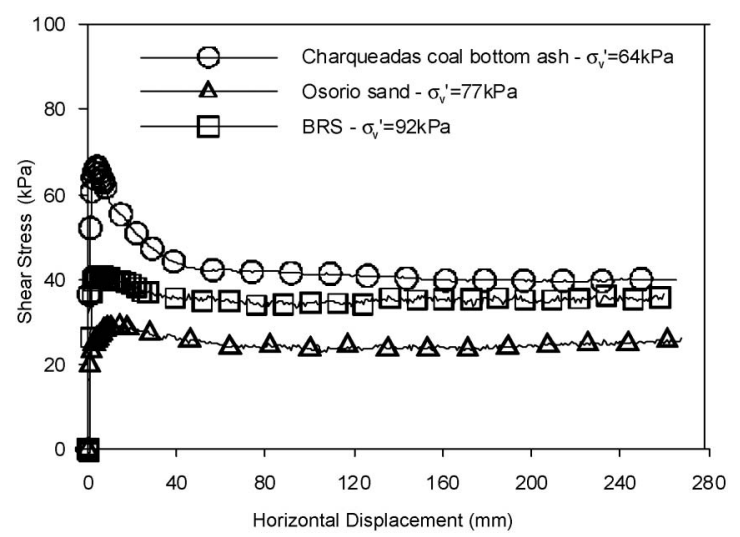

Fig. 11. Ring shear tests on Charqueadas coal bottom ash, Osório sand and BRS

stress:strain curve when sheared at typical engineering stress levels. Comparing the data for the three materials, it can be observed that the bottom ash has the highest values of peak strength for a given confining stress, followed by the Osório sand and finally by BRS. The higher peak strengths correspond to greater dilation rates.

The peak shear strength parameters of the materials studied are presented in Table 7. As expected for coarsegrained soils, the values of cohesion intercept in the Bottom Ash and the BRS are small and is zero for the Osório sand. The Bottom Ash has the highest value of friction angle $\left(44.7^{\circ}\right)$, followed by the Osório sand $\left(35.8^{\circ}\right)$ and the BRS $\left(30.5^{\circ}\right)$.

Figure 11 shows typical data from the ring shear tests conducted on each soil with a normal stress in the range $60-90 \mathrm{kPa}$. These tests were conducted in order to evaluate the shear strength at very large strains, higher than those possible in triaxial tests. Figure 12 presents the ultimate strength envelopes for these ring shear tests and the strength parameters are given in Table 7. For coarsegrained soils the strength measured in ring shear tests should correspond to the critical state or ultimate state and the data should confirm that there is no reduction in strength at very large displacements. The cohesion intercept is zero for the Osório sand, as expected for the ultimate condition and has been assumed also to be zero for the other two soils. The highest value of friction angle was found for the bottom ash $\left(35.0^{\circ}\right)$, followed by the Osório sand $\left(26.6^{\circ}\right)$ and the BRS $\left(20.8^{\circ}\right)$. These friction angles have been calculated making the assumption that $\phi^{\prime}$ can be taken as $\tan ^{-1}\left(\tau / \sigma_{v}^{\prime}\right)$. Therefore in terms of both peak and ultimate strengths, coal bottom ash 


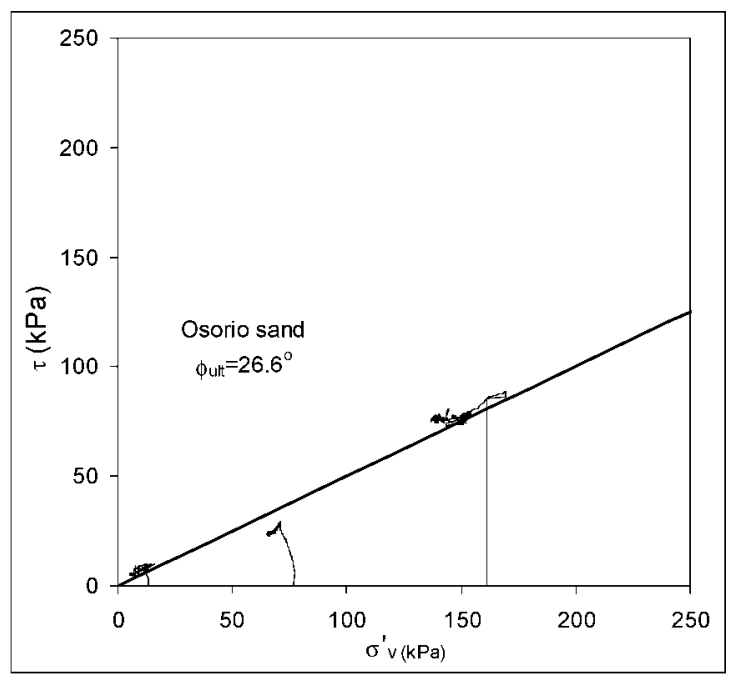

(a)

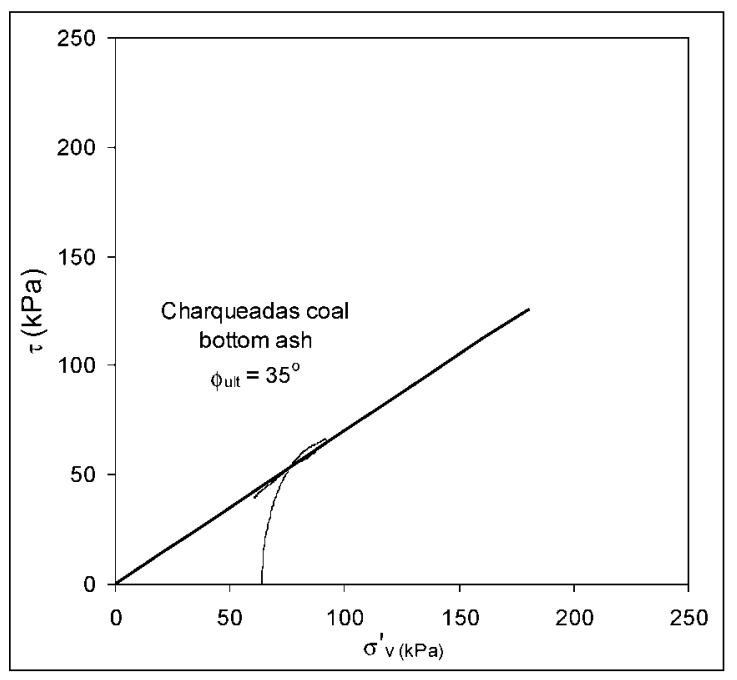

(b)

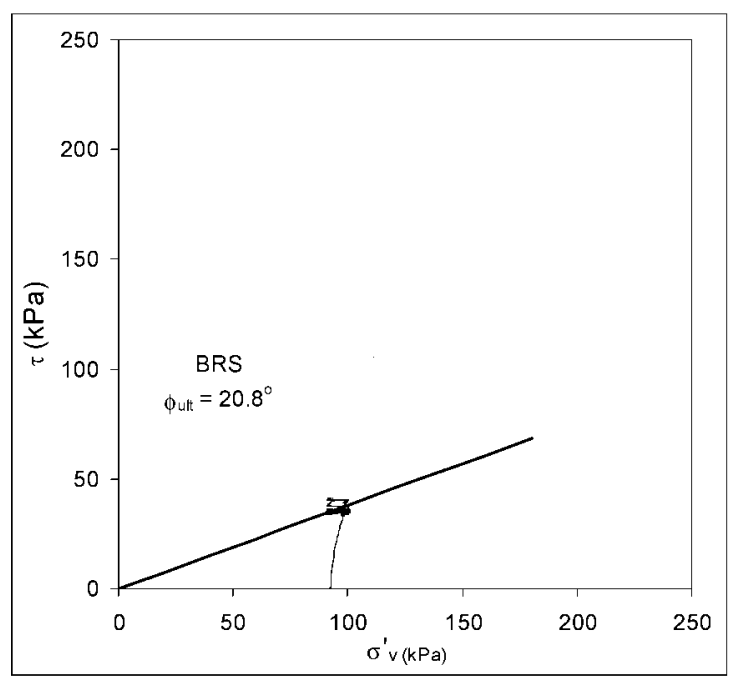

(c)

Fig. 12. Ultimate strength envelopes for ring shear tests on (a) Osório sand, (b) Charqueadas coal bottom ash and (c) Botucatu residual soil (BRS) appears to have better mechanical properties than those of residual granular soils with a similar grading or standard uniform sand with a similar average grain size, which is a valuable characteristic for its use in construction. The friction angles are also likely to be related to the grading and particle morphology of the soils. The wellgraded soil, with a significant fines content has the lowest $\phi^{\prime}$, while the sub-rounded uniform sand gives intermediate values. It is probably the more angular nature of the bottom ash particles, evident in both the thin sections and SEM micrographs that provides it the highest $\phi^{\prime}$ values, despite it being well-graded.

\section{CONCLUSIONS}

An extensive laboratory-testing program was used to investigate the behavior of bottom ash compared to conventional granular materials at high isotropic pressures, very large shear displacements, as well as at very small shear strains. To do so, high-pressure isotropic compression, ring shear and bender elements tests were carried out, as well as standard triaxial tests. The observations and conclusions can be summarized as follows:

1. As suggested by Coop and Lee (1993), for quartzitic sands very high pressures are required to reach the NCL and for the Osório sand, about $15 \mathrm{MPa}$ was necessary. For the Charqueadas bottom ash, the NCL was reached at lower isotropic pressures of about $2 \mathrm{MPa}$. This could result from the high internal porosity and greater angularity of the grains and therefore the higher initial specific volumes and more easily crushable particles. However, the lowest pressure needed to reach its respective NCL occurred for the Botucatu residual soil (about $500 \mathrm{kPa}$ ), which is a silty sandy soil containing some clay, showing that as well as grain morphology, the grain size distribution is also important in the definition of the pressure required to reach the NCL, since the gradings of the BRS and the Bottom Ash are similar.

2. At very small shear strains, the bender element test data confirmed observations from the stress:strain curves of the triaxial tests that the Charqueadas bottom ash has the lowest values of stiffness, followed by BRS and finally Osório sand. The coefficients $A_{0}$ (the intercept at $p^{\prime}=1 \mathrm{kPa}$ ) and $n_{0}$ (the exponent determining the rate of variation of $G_{0}$ with $p^{\prime}$, obtained by fitting a straight line through the $\log \left(G_{0} / p_{\mathrm{r}}\right)-\log \left(p^{\prime} / p_{\mathrm{r}}\right)$ data), are equal to 1206 and 0.653 for the Charqueadas Bottom Ash and 5186 and 0.596 for BRS, which are within the range of variation observed in conventional granular materials. The lower stiffness of the bottom ash may be related to its higher voids ratio, which may be reflected in a smaller number of particle contacts, or it may be a function of the nature of the particles.

3. From the stress-strain data of the standard triaxial tests it can be concluded that for samples compacted to the maximum density achieved in the standard 
Proctor test and then sheared at typical engineering stress levels, the Charqueadas Bottom Ash shows a marked softening behavior after peak. The Osório sand (at 70\% relative density) and BRS specimens show less strain softening, corresponding to smaller rates of dilation. The peak shear strength parameters of the three materials gave small or zero values of cohesion intercept with the highest value of friction angle for the Bottom Ash $\left(44.7^{\circ}\right.$ ), followed by the Osório sand $\left(35.8^{\circ}\right)$ and $\operatorname{BRS}\left(30.5^{\circ}\right)$. The highest ultimate friction angle, determined by ring shear tests, was found for the Bottom Ash $\left(35.0^{\circ}\right)$, followed by the Osório sand $\left(26.6^{\circ}\right)$ and BRS $\left(20.8^{\circ}\right)$. In terms of peak and ultimate strength, the coal bottom ash therefore has a higher strength than both a soil with a similar grading and standard uniform sand with similar average grain size.

In summary, the Bottom Ash has a higher strength although it has a lower stiffness than other typical sands. Since it would not reach particle yield on its Normal Compression Line at typical engineering stress levels, its compressibility should not pose problems. It therefore appears to be a suitable material for widespread use in many Civil Engineering applications.

\section{ACKNOWLEDGMENTS}

The authors wish to express their gratitude to PRONEX/FAPERGS (Process \# 04/0841.0) and CNPq-Brazilian Council of Scientific and Technological Research (Projects Produtividade em Pesquisa \#300832/2004-4, Edital Universal 2004 \#472643/2004-5 and Pós-Doutorado no Exterior \#200957/2005-8) for their financial support to the research group.

\section{NOTATION}

A: Intercept at $1 \mathrm{kPa}$ for $\log G_{0}: \log p^{\prime}$ relationship

ABMS: Brazilian Standard Association

ASTM: American Society for Testing and Materials

B: Pore pressure parameter

BRS: Botucatu Residual Soil

$c_{\text {peak }}^{\prime}$ : Cohesion intercept for peak states

CID: Consolidated Isotropically Drained triaxial test

D: Diameter

$D_{10}$ : Effective diameter

$D_{50}$ : Average diameter

$e$ : Voids ratio

$G$ : Shear modulus

$G_{0}: \quad$ Elastic shear modulus

$G_{\max }:$ Maximum shear modulus

$L$ : Length between bender elements

$n$ : Inclination of $\log G_{0}: \log p^{\prime}$ relationship

$N$ : Intercept of NCL in $v: \ln p^{\prime}$ plane at $1 \mathrm{kPa}$.

NCL: Normal Compression Line

$p_{\mathrm{e}}^{\prime}$ : Equivalent pressure

$p_{\mathrm{r}}:$ Reference pressure $(=1 \mathrm{kPa})$

$p^{\prime}:\left(\sigma_{1}^{\prime}+2 \sigma_{3}^{\prime}\right) / 3$

$q: \quad\left(\sigma_{1}^{\prime}-\sigma_{3}^{\prime}\right)$

PP: Particle pore

$R_{0}$ : Overconsolidation ratio

SEM: Scanning Electron Microscopy

$t$ : Travel time of the shear wave through the sample $v$ : Specific volume

$V_{\mathrm{s}}$ : Velocity of the shear wave through the sample

$w$ : Water content

$w_{\text {opt }}:$ Optimum water content

$\varepsilon_{\mathrm{a}}: \quad$ Axial strain

$\varepsilon_{\mathrm{s}}:$ Shear strain $\left(=\varepsilon_{\mathrm{a}}-\varepsilon_{\mathrm{v}} / 3\right)$

$\varepsilon_{\mathrm{v}}$ : Volumetric strain

$\rho:$ Total mass density

$\lambda$ : Gradient of the NCL in $v: \ln p^{\prime}$ plane

$\gamma_{\mathrm{d}}$ : Dry unit weight

$\gamma_{\text {dmax }}$ : Maximum dry unit weight

$\phi_{\text {peak }}^{\prime}$ : Peak friction angle

$\phi_{\text {ultimate: }}^{\prime}$ Ultimate friction angle

\section{REFERENCES}

1) ABNT NBR 10004 (1987): Solid Residues, Brazilian Standard Association, Rio de Janeiro, Brazil (in Portuguese).

2) Andrade, A. (1985): Characterization of coal ashes from Candiota, M.Sc. Thesis, Federal University of Rio Grande do Sul, Porto Alegre, Brazil (in Portuguese).

3) ASTM D 2487 (1993): Standard Classification of Soils for Engineering Purposes, American Standards for Testing and Materials, Philadelphia.

4) Binotto, R. B., Teixeira, E. C., Sánchez, J. C., Nanni, A. S., Fernandes, I. D. and Migliavacca, D. M. (1999): Characterization of residues from coal processing activities in southern Brazil, Technical Report FEPAM, Porto Alegre, Rio Grande do Sul, Brazil (in Portuguese).

5) Bishop, A. W., Green, G. E., Garga, V. K., Andersen, A. and Brown, J. D. (1971): A new ring shear apparatus and its application to the measurement of residual strength, Géotechnique, 21(4), 273-328.

6) Calarge, L. M., Silva, N. I. W., Chies, F. and Zwonok, O. (1998): Characterization of Brazilian coal bottom ashes, 2nd Int. Symp. Environment Quality, Catholic University of Rio Grande do Sul Press, Porto Alegre, Brazil, 1, 122-126 (in Portuguese).

7) Clayton, C. R. I. and Khatrush, S. A. (1986): A new device for measuring local axial strains on triaxial specimens, Géotechnique, 36(4), 593-597.

8) Clayton, C. R. I., Khatrush, S. A., Bica, A. V. D. and Siddique, A. (1989): The use of Hall effect semiconductor in geotechnical instrumentation, Geotech. Test. J., 13(3), 235-242.

9) Coop, M. R. and Atkinson, J. H. (1993): The mechanics of cemented carbonate sands, Géotechnique, 43(1), 53-67.

10) Coop, M. R. and Lee, I. K. (1993): The behaviour of granular soils at elevated stresses, Predictive Soil Mechanics, Thomas Telford, London, UK, 1, 186-198.

11) Coop, M. R. and Jovicic, V. (1999): The influence of state on the very small strain stiffness of sands, 2nd Int. Symp. Pre-failure Deformation of Geomaterials, IS-Torino 99, Turin, Italy, 175-181.

12) Coop, M. R. and Airey, D. W. (2003): Carbonate sands, Characterisation and Engineering Properties of Natural Soils (eds. by Tan et al.), Swets \& Zeitlinger, Lisse, 1049-1086.

13) Cuccovillo, T. and Coop, M. R. (1997): The measurement of local axial strains in triaxial tests using LVDTs, Géotechnique, 47(1), 167-171.

14) Cuccovillo, T. and Coop, M. R. (1999a): An automated triaxial apparatus for elevated pressures, Non-Destructive and Automated Testing for Soil and Rock Properties, ASTM Symp. In Print, STP 1350 (eds. by Marr, W. A. and Fairhurst, C. E.), ASTM, West Conshohocken, 231-246.

15) Cuccovillo, T. and Coop, M. R. (1999b): On the mechanics of structured sands, Géotechnique, 49(6), 741-760.

16) Ferreira, C. (2002): Implementation and application of electrical transducers in determining velocity of seismic waves: evaluation of sampling quality in residual soils, M.Sc. Thesis, Engineering Faculty-University of Porto, Porto, Portugal (in Portuguese).

17) Gupta, N., Brar, B. S. and Woldesenbet, E. (2001): Effect of filler addition on the compressive and impact properties of glass fiber 
reinforced epoxy, Bulletin of Materials Science, Indian Academy of Science, 24(2), 219-223.

18) Heineck, K. S. (2002): Mechanical and hydraulic behavior of new geotechnical materials, Ph.D. Thesis, Federal University of Rio Grande do Sul, Porto Alegre, Brazil (in Portuguese).

19) Huang, H. W. (1990): The use of bottom ash in highway embankments, subgrade, and sub-bases, Joint Highway Research Project, Final Report, FHWA/IN/JHRP-90/4, Purdue University, W. Lafayette, Indiana.

20) Huang, H. W. and Lovell (1990): Bottom ash as embankment material, Geotechnics of Waste Fills-Theory and Practice, ASTM STP 1070, 71-85.

21) Jovicic, V., Coop, M. R. and Simic, M. (1996): Objective criteria for determining $G_{\max }$ from bender element tests, Géotechnique, 46(2), 357-362.

22) Jovicic, V. and Coop, M. R. (1997): Stiffness of coarse-grained soils at small strains, Géotechnique, 47(3), 545-561.

23) Kim, B., Prezzi, M. and Salgado, R. (2005): Geotechnical properties of fly and bottom ash mixtures for use in highway embankments, J. Geotech. Geoenviron. Engrg., 131(7), 914-924.

24) Ladd, R. S. (1978): Preparing test specimens using undercompaction, Geotech. Test. J., ASTM, 1(1), 16-23.

25) Lade, P. V. and Bopp, P. A. (2005): Relative density effects on drained sand behavior at high pressures, Soils and Foundations, 45(1), 1-13.

26) La Rochelle, P., Leroueil, S., Trak, B., Blais-Leroux, L. and Tavenas, F. (1988): Observational approach to membrane and area corrections in triaxial tests, Proc. Symp. Advanced Triaxial Testing of Soil and Rock, ASTM, Louisville, 715-731.

27) Lee, K. L. and Seed, H. B. (1967): Drained strength characteristics of sands, Proc. ASCE, J. Soil Mech. Found. Engrg., 93(SM6), $117-141$.

28) Maswoswe, J. J. (1985): Stress path method for a compacted soil during collapse due to wetting, Ph.D. Thesis, University of London.

29) Miura, N. and Yamonouchi, T. (1975): Effect of water on the behaviour of quartz-rich sand under high stresses, Soils and Foundations, 15(4), 23-34.

30) Pettijohn, F. J., Potter, P. E. and Siever, R. (1987): Sand and Sandstone, New York: Springer-Verlag, Second Edition.

31) Qadimi, A. (2005): The cyclic response of a carbonate sand through critical state soil mechanics, Ph.D. Thesis, Imperial College, London.

32) Rio, J. F. M. E. (2006): Advances in laboratory geophysics using bender elements, Ph.D. Thesis, University College, London.

33) Sanchez, J. C. D. (1987): Heavy metals from fly ash produced by coal-burning electric utilities in southern Brazil, M.Sc. Disserta- tion, Federal University of Rio Grande do Sul, Porto Alegre, Brazil (in Portuguese).

34) Sanchez, J. C. D., Teixeira, E. C. and Fernandes, I. D. (1996): Study of elements mobility from coal combustion ashes using different methods, SWEMP'1996 (ed. by Ciccu, R.), Santa Margherita di Puglia, Italy, 1, 1169-1176.

35) Santucci de Magistris, F., Silcestri, F. and Vinale, F. (1998): The influence of compaction on the mechanical behaviour of a silty sand, Soils and Foundations, 38(4), 41-56.

36) Seals, R. K., Moulton, L. K. and Ruth, B. E. (1972): Bottom ash: An engineering material, J. Soil Mech. Found. Div., 98(4), 311-325.

37) Shirley, D. J. and Hampton, L. D. (1977): Shear-wave measurements in laboratory sediments, J. Acoustics Society of America, 63(2), 607-613.

38) Tessari, M. A., Vieira, L. F. and Consoli, N. C. (1998): Interpretation of loading tests bearing on layers of coal bottom ash treated with cement, 3rd Int. Cong. Environmental Geotechnics, A. A. Balkema, Pedro Seco e Pinto Editor, Lisbon, Portugal, 1, 727-730.

39) Thomé, A., Carraro, J. A. H., Balvedi, D. and Consoli, N. C. (1998): Utilisation of industrial by-products for soil stabilization and the influence of temperature in the development of pozzolanic reactions, 3th Int. Cong. Environmental Geotechnics, A. A. Balkema, Pedro Seco e Pinto Editor, Lisbon, Portugal, 1, 721-726.

40) Thomé, A., Donato, M. and Consoli, N. C. (2003): Loading tests on compacted soil-bottom ash-carbide lime layers, Soils and Rocks, São Paulo, 26, 51-68 (in Portuguese).

41) Tovey, N. K. (1986): Microfabric, chemical and mineralogical studies of soils: techniques, Geotech. Engrg., Bangkok, 17, 131-163.

42) Vesic, A. S. and Clough, E. W. (1968): Behavior of granular materials under high stresses, Proc. ASCE, J. Soil Mech. Found. Engrg., 94(SM3), 661-688.

43) Viana da Fonseca, A. (1996): Geomechanics in residual soils from Porto granite: Criteria for the design of shallow foundations, Ph.D. Thesis, University of Porto (in Portuguese).

44) Viana da Fonseca, A. (2003): Characterizing and deriving engineering properties of a saprolitic soil from granite, in Porto, Characterisation and Engineering Properties of Natural Soils (eds. by Tan et al.), Swets and Zeitlinger, Lisse, 1341-1378.

45) Viana da Fonseca, A., Carvalho, J., Ferreira, C., Costa, E., Tuna, C. and Santos, J. A. (2004): Geotechnical characterization of a residual soil profile: the ISC'2 experimental site, FEUP, Geotechnical and Geophysical Site Characterization, Millpress, Rotterdam, Eds. Viana da Fonseca and Mayne., 1361-1369.

46) Viggiani, G. and Atkinson, J. H. (1995): Stiffness of fine-grained soils at very small strains, Géotechnique, 45(2), 249-265. 